The Politics of Culture and the Space for Islam: Soviet and Post-Soviet Imaginaries in Uzbekistan

Johan Rasanayagam

Senior Lecturer in Social Anthropology, School of Social Science, University of Aberdeen, UK

School of Social Science

University of Aberdeen

Aberdeen

AB24 3QY

UK

johan.rasanayagam@abdn.ac.uk 


\title{
The Politics of Culture and the Space for Islam: Soviet and Post-Soviet Imaginaries in Uzbekistan
}

\begin{abstract}
This article examines how possibilities for Muslim expression are shaped by the political imaginaries in Soviet era and independent Uzbekistan. It develops the concept of social imaginary in Charles Taylor's critique of western secular modernity. Political imaginaries are the assumptions about the nature of being, the essential categories through which the world is understood and acted upon, that are produced within dominant state discourses and that shape the space for the political. The article compares the Soviet vision of socialist modernity and the logic of the current state ideology in independent Uzbekistan, and discusses how these have framed the possibilities for being Muslim. It argues that the category of culture is produced in distinct and contrasting ways in these imaginaries, and plays a central role in delineating the public space for Islam.
\end{abstract}

Keywords: Uzbekistan, Islam, politics, culture, state

What is the public space for being Muslim in Uzbekistan? A number of scholars have pointed to the effects of the securitization of Islam by Central Asian governments in the context of an international "war on terror" (Omelicheva 2011). They have explored the efforts of these governments to authorise their own approved forms of religious expression, and to repress those they characterise as "extremist" and dangerous to social and political stability, a situation that is particularly acute in Uzbekistan. Adeeb Khalid has argued that the government of Uzbekistan exaggerates the threat of these groups in order to control Islamic practice, and has in effect created a category of "independent Muslims" who practice Islam independently of the state (Khalid 2007: 168-91). Russell Zanca has pointed out that these efforts can alienate Muslim populations and perhaps increase opposition to established regimes (Zanca 2005; see also Trisko 2005). This article seeks to contribute to this discussion by exploring the logic of official state discourse in Uzbekistan, placing Soviet and post-independence discourses in 
comparative perspective. It develops the concept of political imaginary to capture how this logic extends beyond the official texts of state ideology. Political imaginary refers to the logic and foundational categories that underlie these textual productions which, in turn, constitute the logic of the interventions of state officials in the lives of citizens, and in terms of which citizens must present themselves in public space. The concept of political imaginary helps us to understand why a Muslim convert to a Christian denomination might be arrested for possessing the Bible in contemporary Uzbekistan despite the fact that possessing the Bible is not illegal, or why that convert might even be accused of being a Wahhabi.

Within the Soviet Union religious expression was closely regulated, a situation that has continued after Uzbekistan became an independent state in 1991. Both regimes, in their different ways, have sought to regulate social space and to define correct "citizen subjects". The New Soviet Person was ideally to be an enlightened, rational subject who had internalised an ethic of socialist modernity that left no space for religious belief. This has given way to the komil inson, the "perfect" or "complete" person, constructed in Uzbekistan's "Idea of National Independence" as the embodiment of a cultural and spiritual Uzbek authenticity. This post-independence state ideology posits a return to an authentic Central Asian cultural and spiritual heritage, purported to have been suppressed during Soviet rule, that encompasses a specifically Central Asian Islam (Rasanayagam 2011: 103-10). In practical terms, the new ideology is intended to naturalise the territory of Uzbekistan as an ethnonational state and to legitimate the authoritarian rule of the present regime led by president Karimov.

The significance of these ideologies is not that they are successful in actually transforming human subjects and shaping consciousness. As the historian of the Soviet Union Stephen Kotkin has put it, people learned to speak Bolshevik in public, while simultaneously inhabiting a counter -society of circumventions and localised resistances. They learned to "work the system to their minimum disadvantage" (Kotkin 1995: 237). Hegemony can be productively understood as defining the character and logic of public performance rather than as shaping an interior state of belief (Scott 1985; Yurchak 2006). State ideology in Soviet and independent Uzbekistan is significant because it is productive of what might be called the "political". It makes action and events in certain contexts or circumstances public, and determines how individuals must present themselves and their actions in this public space. 
This article examines the distinctive political imaginaries of Soviet and postindependence state discourses, and how the latter emerges out of, but is also radically a departure from, the Soviet experience. It explores the conceptions of culture produced within these imaginaries, and how they shape the possibilities for the public performance of Muslim practice. I am adapting the concept of imaginary from the philosopher Charles Taylor's writing on western secular modernity. Taylor develops an analysis of a plurality of conceptual worlds. He seeks to displace western secular modernity from its position as the teleological endpoint of a universal human evolutionary progress, and locates it as just one possible modern among others (Taylor 2004). Taylor employs "social imaginary" to refer to:

the ways people imagine their social existence, how they fit together with others, how things go on between them and their fellows, the expectations that are normally met, and the deeper normative notions and images that underlie these expectations (Taylor 2004: 23).

Taylor employs social imaginary to encompass a diffuse contemporary western "culture". The anthropologist Morgan Liu has taken inspiration from Taylor's writing to develop a concept of socio-political imaginary in the context of Kyrgyzstan. For Liu, this is intended to capture the "grasp people have of the conventional actors, groups, actions, places, contexts, times, meanings, and interests involved in their collective life", the "explicit ideologies about society but also embodied social practice" (Liu 2012:14). Unlike Taylor and Liu, I am not employing imaginary to refer to diffuse culture or an embodied habitus that informs everyday experience. I am restricting my analysis to state ideological production. But ideology extends beyond the specific texts and pronouncements of state officials. In this article I show how the hegemony of official state discourse is materialised in its performance. ${ }^{1}$ Taylor's analysis is useful for grasping this performative and dynamic quality because it draws attention beyond the surface text to the logics, the categories for thought and action, that constitute the conceptual worlds of state ideologies. These logics or imaginaries shape the way that state officials intervene in the lives of citizens, and how citizens are forced to present themselves in public space, in ways that go beyond the texts themselves.

The anthropologist Bruce Kapferer has used the notion of ontology in a similar way in relation to nationalist discourses. Cosmic ontology, for Kapferer, refers to the fundamental principles of being in the world. He contrasts Sri Lankan Buddhist and 
secular Australian nationalisms. The former constructs a hierarchal order where the state protects and guarantees the integrity of both the nation and (Buddhist) person in the face of threatening, fragmentary elements, namely Tamil separatist movements. Australian nationalism presents a vision of egalitarian individualism where the state itself can become the threat to the integrity of the (autonomous) person if it assumes a dominant and inclusive relation to the nation. Kapferer is interested in how state level nationalist discourse articulates with ordinary practices of everyday life and engages the emotions. He argues that the ontology of nationalist discourse is also present in everyday worlds, that nationalism becomes linked with identical logics of being that orient everyday experience. What nationalism seeks to do is to co-opt and discipline the heterodox and dynamic everyday experience and practice within an orthodoxy so as to frame experience and perception (Kapferer 1988).

I am not employing the idea of imaginary to capture the logics of everyday lifeworlds. However both Taylor's concept of imaginary and Kapferer's focus on ontological logics direct attention to the normative categories through which the nation and the citizen are produced within state discourse, and the sources of authenticity that lie at the heart of state projects. These shape the space for the political in Uzbekistan. How do Soviet and post-Soviet state projects construct the nation and the relation between state and citizen? What concept of personhood, history and progress do they produce? How are categories such as public and private, modernity and tradition defined? Key to understanding the essential divergences between the Soviet and postSoviet political imaginaries in Uzbekistan, and how they create different public spaces for being Muslim, is the category of culture.

\section{A question of culture}

The category of culture produced within state political imaginaries creates possibilities for religious expression, and this is particularly evident in cases of conversion to Christianity by members of "traditionally" Muslim populations. The experience of one such convert I encountered in Samarkand during field research in 2004 is illustrative. ${ }^{2}$ Ahmadjon is a Tajik speaker of "Arab" nationality. ${ }^{3} \mathrm{He}$ encountered Christianity some years before our meeting through his mother's illness and their search for a cure, a feature of several conversion narratives I heard in Samarkand. Conventional biomedical treatment proved ineffective, and the family had recourse to a number of healing 
strategies. They called on mullahs to read passages of the Qur'an over his mother, visited the shrines of avliyo, or "saints", and turned to folbin, healers who invoked the aid of spirits. Eventually, a Christian pastor told Ahmadjon about Jesus and they visited the prayer meetings of this unregistered Protestant group, which took place in a private house. His mother recovered her health through attending these meetings, and Ahmadjon's household, which includes his parents, his three married brothers and their families, have all become Christians. Ahmadjon became an active member of this Christian group, assisting the pastor, who is Russian, with translations into Tajik and Uzbek. Ahmadjon recounted his own internal conflict and the ongoing opposition of neighbours in his mahalla, which is called Arabkhona and is populated predominantly by people of Arab nationality like himself. He considered himself a real Muslim unlike the Tajiks (who make up the majority of Samarkand's urban population) because, as an Arab, he has the Prophet's blood in his veins, and how can a Muslim believe in Jesus? Many of his neighbours were putting pressure on the family to revert back to being Muslim. After he became a Christian, they accused him of selling out his religion, and even of being a "Wahhabi". Rather than theologically based notions of apostasy, in large part these objections stemmed from the idea that it is unnatural for a member of one of the indigenous Central Asian populations to be anything other than Muslim. Similarly, it would be unnatural for a European Russian to be anything other than Orthodox Christian.

The identification of religion with ethno-national identity in Central Asia has been traced to the colonial incorporation of the region within the Tsarist Empire. Shirin Akiner has argued that it emerged in the contact and opposition between the indigenous population that was predominantly Muslim, and non-Muslim settlers and administrators, mainly Christian Slavic (Akiner 1997). This identification as it is manifested in the contemporary period is also in large part a product of Soviet nationalities policy that was founded on a primordialist vision of ethno-national belonging, defined in terms of language, culture and territory, and an evolutionary theory of development through defined historical stages (Hirsch 2005; Slezkine 2000). A number of historians of Central Asia have argued that this policy has produced a "secular" or "cultural" Islam. Notably, Nazif Shahrani has argued that the political culture of "scientific atheism" inculcated through the system of education, in combination with the restrictions on religious practice that cut off the vast majority of Soviet Muslims from access to 
knowledge of the sacred texts and from developments in Muslim thought throughout most of the $20^{\text {th }}$ century, enhanced by the politics of "fear and favour", succeeded to a significant degree in colonising the consciousness of Central Asians (Shahrani 1995). Along similar lines, Adeeb Khalid argues that under Soviet rule religious knowledge shrank drastically and Islam survived as an aspect of a localised national tradition. It became little to do with personal belief or ritual observance, but served to mark indigenous Central Asians from the Slavic and other European populations settled in the region. Soviet anti-religion policies destroyed the means through which Islamic knowledge was produced and transmitted, and prevented the daily ritual practice that was centred on mosques and conducted in public space. At the same time, the Soviet state support for national forms allowed Islam to survive as an element within what came to be regarded as Central Asian national custom, such as wedding celebrations, music, and national costume (Khalid 2003; 2007). ${ }^{4}$

The fusion of religion with ethno-national identity gives a particular quality to the dilemmas faced by Central Asians who become Christian believers. It forces them to confront the unnaturalness of a Central Asian Christian by separating out the categories of culture and belief. As described by a number of indigenous Central Asian members of Protestant Christian groups I encountered in Samarkand, this process is not so much a "conversion" from one belief system to another, but a primary entry into a state of belief. They described their former selves, along with the majority of self-ascribed Muslims in Uzbekistan, as "cultural Muslims" who rarely, if ever, fulfilled Islamic ritual prescriptions. Ahmadjon's reply to accusations that he sold out his religion is that he had no real belief in the first place that he could have betrayed. A feature of many conversion narratives is a separating out of an internal state of belief (in Jesus) from an external cultural practice (as Muslim). ${ }^{5}$

The accusation levelled at Ahmadjon of being a Wahhabist hints at a further dimension to the "unnaturalness" of a Central Asian Christian, one which is more particular to Uzbekistan and the political imaginary produced by the post-independence state. This accusation, levelled at a convert to Christianity, might at first seem puzzling given that Wahhabism is a specifically Islamic movement. The mullah of the local mosque had threatened to report Ahmadjon's father to the internal security services, and a school in Arabkhona had been visited by the security services, who had taken down the names of all children who had become Christian. The direction of the accusation of 
Wahhabism at Christian converts receives its logic from Uzbekistan's postindependence political imaginary. The present government has identified political Islamism as a major threat to its own authority, and religious expression, particularly Islamic, is liable to be suppressed ruthlessly if it is perceived as independent of state authorised definitions of culturally authentic Central Asian Islam (Rasanayagam 2006; Khalid 2007). In the context of the present regime's emphasis on cultural authenticity, the label of Wahhabi extends beyond Islam to any "unnatural" practice which might seem to be religious in some way. The political imaginary of independent Uzbekistan inherits from the Soviet regime an association between culture and religion but, as I will explore more fully in the following section, publicly embodying a cultural authenticity, within the logic of the post-independence political imaginary, has become a critical dynamic of the political, in order to establish oneself as a "correct" Uzbek subject and citizen. Cultural authenticity has become a matter of national security.

\section{Imaginaries of secular modernity}

A recurring topic of controversy in Uzbekistan is the appropriate conduct of life cycle events; marriages, circumcisions and funeral commemorations. They have generally had to be curtailed in scale because of the economic hardship that much of the population has experienced since the breakup of the Soviet Union, with the consequent disintegration of means of livelihood and withdrawal of social provision by the state. Even so they continue to be relatively lavish affairs that can impose an onerous burden on household budgets. A marriage can involve multiple feasts. In the event of a death, relatives and neighbours typically pay their respects in the days immediately afterwards, on the Thursdays of the weeks following, and special commemorations are organised on the third, twentieth and fortieth days, as well as a year after the funeral. These occasions represent a significant financial expense as visitors need to be given a meal, and a mullah or a qori (Qur'an reciter) needs to be hired to recite the Qur'an and say prayers. In the case of funerals, these expenses cannot be planned for, which increases the material burden they represent.

Imams appointed by the state controlled Muslim Board of Uzbekistan to manage officially registered mosques, as well as many other Muslims who have gained knowledge of the sacred texts and their interpretation (often in one of the madrasas which have opened since independence under the control of the Muslim Board) 
condemn extended feasts as contrary to the $\operatorname{sharī~}^{\prime} a$. They point to the exemplary practice of the Prophet who was mourned for only three days by his closest followers and criticise anything in excess of this as illegitimate innovation, the product of a misguided human tradition. For imams, the material hardship caused by these events is further proof of their illegitimacy as there is nothing in Islam properly understood, they argue, which would cause harm to Muslims.

As Sergei Abashin (1999) has observed, their criticisms are seemingly in line with current government policy that calls for moderation in expenditure. During the Soviet period, too, religious rituals were a target for attack by state and Communist Party activists, but in each of these cases criticism is framed within different rationalities. Soviet criticism, sometimes reflected in the accounts of Soviet ethnographers, emerges from the logic of the project of socialist modernity intended to transform "traditional" Central Asian society and fashion new Soviet persons. ${ }^{6}$ In this vision, the extravagant expenditure on ritual was irrational waste, a non-productive use of resources. It was part of pre-modern tradition, religion and superstition which needed to be discarded to allow the emergence of rational, scientific thinking and the development of a truly socialist society and citizenry.

The criticisms of the post-independence government are framed very differently. Here, tradition is not presented as an obstacle to rationality and progress. Rather, cultural authenticity and the "Golden Heritage" of the nation is constructed as the authentic source for the Idea of National Independence developed to replace Marxist Leninism as the legitimating ideology of nationhood. On a practical level, the government is no doubt worried that the excessive expenditure on lifecycle events highlights growing inequalities and levels of poverty since independence, but it couches its criticism not in terms of scientific rationality, but presents such behaviour as contrary to historically rooted national spiritual values (Abashin 1999).

The criticism of imams invokes yet another frame. They criticise extended feasting as bid'at, illegitimate innovation outside the bounds of the $\operatorname{sharì~}^{-} a$ and therefore something Muslims should not engage in. While presenting their position as fully in support of government policy, the understanding of tradition invoked is very different. Through a study of the sacred texts, albeit within madrasas controlled by the Muslim Board, imams view Islam as God's Truth that transcends geographical and cultural borders, even if some allowances might be made for local norms and customs. 
The post-independence government locates its discourse of nationhood in the "Golden Heritage" but tradition and custom, urf-odat, is for the imams a fallible, contingent, human creation in opposition to the divine Truth materialised in the physical universe and articulated as God's Speech, the Qur'an.

A discussion of Charles Taylor's concept of social imaginary brings out the distinctive rationalities of these different positions, and the critical importance of the category of culture. What is central to western modernity, Taylor argues, is a new conception of a moral order for society which identifies human agency as the creative source of social formations. While in a pre-modern order social systems of hierarchy and differentiation might express or correspond to the given order of the cosmos, within the modern order it is human beings who create society in secular time, in the course of the historical succession of events as opposed to an unchanging or eternal higher time. Human beings come to be imagined within a state of nature in which humans stand outside relations of hierarchy and status, as rational individuals who join together within society for mutual benefit. Ideals of justice and equality are understood as natural rights, as human goods rather than as originating in any supernatural location. Modern society is therefore horizontal and egalitarian, as opposed to the vertical, hierarchical ordering of society on the basis of essential differences in classes of persons, such as nobles and serfs, or hereditary castes (Taylor 2004). The perception of this state of nature is imagined as clouded or suppressed by traditional beliefs and false superstitions, and historical progress towards the modern era of empirically founded, scientific truth is conceived as the liberation of the individual from artificial constraints of pre-modern thinking (Taylor 2007).

I find Taylor's analysis productive for understanding the Soviet and post-Soviet condition because it directs us to the sources of authenticity that inform the rationalities of different imaginaries. Within Taylor's western secular modern, authenticity is located in the inherent value of the human subject, and in human creativity enacted in historical time, what he refers to as the "immanent frame". In both the western and Soviet versions of modernity, the natural freedom of the autonomous, rational individual is imagined as being suppressed or clouded within pre-modern orders and their associated traditional modes of thought or false consciousness. By contrast, in the ideological discourses of the independent state of Uzbekistan, tradition is not constructed as an impediment to enlightenment, but rather an authentic cultural heritage is posited as the 
foundation for a distinctive Central Asian modernity of economic, political and spiritual development. The Golden Heritage is the source of an Uzbek authenticity.

The Soviet project, particularly in its early decades up to the end of the Stalinist period, involved a concerted attempt to transform the human subject. David Hoffmann has described this essentially as a process of enculturation (Hoffmann 2003). In Soviet ideological discourse, the concept of kul'turnost', or "culturedness", implied not only high culture but civilised behaviour. The civilising mission was aimed at fashioning subjects who internalised new behavioural norms and values, and rational dispositions of efficiency, hygiene, sobriety and literacy. Kul'turnost' might be understood as the embodiment of a socialist rationality. In opposition to the competitive, egoistic individualism of bourgeois capitalist societies, the New Soviet Person was to enter society as part of a collective, achieving his or her human potential in the pursuit of collective, rather than individual, goals. Enculturation was to be achieved not just through ideological pronouncements from the centre, but was worked out through the capillaries of society, in the work place, leisure activities, and living spaces, and through practices of peer and self criticism (Kharkhordin 1999; Kotkin 1995).

A good examination of how this worked in practice is provided by Medlin, Cave and Carpenter, in their study of education in Soviet era Uzbekistan in the early 1960s. They described the development of "moral education" in the Soviet school, designed to instil the communist consciousness. Moral training was integrated into a range of subjects such as literature, history and geography, which was included in a block called "Political Education". A Soviet morality was also instilled in the organisation of pupils in classroom collectives to aid their learning in how to monitor their own conduct and that of their peers, and to develop a consciousness of working as part of a larger collective extending to the school as a whole, and beyond. Student collectives formed work groups for sharing physical tasks around the school such as maintenance of the buildings and gardening. Group leaders were appointed, a post that was rotated among members of the collective. The goal of moral education, as these authors report it, was to instil a scientific outlook, an appreciation for labour, socialist patriotism and to achieve the all-round harmonious development of the individual in physical, intellectual and aesthetic qualities (Medlin, Cave, and Carpenter 1971). Hoffmann identifies similar language in a 1920 Commissariat of Health report entitled "The Tasks of Physical Culture". This report stressed that physical exercise should promote health, but also 
"create the harmonious individual and complete individual from whom one can expect qualities of most benefit for the common good" (Hoffmann 2003: 35-6). The idea of "moral education" and the language of the "complete" and "harmonious" person finds its echo in the komil inson, the "perfect person" of Uzbekistan's Idea of National Independence, but as we shall see, within a very different conceptualisation of culture.

In contrast to the positively valued Soviet kul'turnost' were perezhitki, or "survivals", the backward cultural forms, institutions and traditions from the past that hindered the progress of socialist transformation. Francine Hirsch captures the Soviet category of survivals in her book Empire of Nations in which she discusses early Soviet nationalities policy. The chapter on ethnographic exhibits in Soviet museums describes how they were designed to display the different peoples of the USSR as experiencing a period of rapid economic and cultural uplift. The conceptual frame employed was the evolutionary path of ethnonational development through defined historical stages, and the exhibits showed how the peoples of the Soviet Union were being accelerated along the path towards a scientifically founded socialist modernity. They also depicted the outmoded cultural forms and traditional beliefs, the survivals that continued to hold up progress. At worst, these were the "class enemies" such as feudal landowners, clan leaders, or shamans, and in Central Asia, Muslim figures such as ishans and mullahs (Hirsch 2005). It is in this opposition between a progressive and enlightened Soviet kul'turnost', which both reflected and produced a socialist society, and harmful, regressive, pre-modern cultural survivals, that we need to understand the Soviet concept of national culture. The national forms of music, dress, dance, food and so on, were folkloric, neutral containers that stood outside these two politically loaded categories of culture. They were to be filled by a socialist content or, as Mathjis Pelkmans has described in the case of Kygyzstan, could be co-opted by Protestant missionaries after socialism for a Christian orientation of personal belief (Pelkmans 2007).

With independence in 1991, the ruling elites in Uzbekistan were faced with the task of developing a narrative of nationhood. The essential themes of this vision are summarised in a government publication entitled "The Idea of National Independence" (Milliy istiqlol g'oyasi, hereafter referred to as MIG). Post-independence ideology owes much to the Soviet legacy. The very existence of Uzbekistan as a territorially defined nation state, founded on principles of ethnicity, language and national culture is a fundamental inheritance of Soviet nationalities policy, but the influence of Soviet 
ideological practice extends far beyond this. The need for a national ideology is itself founded on the Soviet view that individual consciousness is a reflection of a material order of society. An important theme in post-independence state discursive production is the need to fill the "ideological vacuum" left by the collapse of the Soviet project, and to provide "ideological immunisation" especially for younger generations (Karimov 1997: 34; MIG 7, 39-42). ${ }^{7}$ Soviet influence is evident in much of the key terminology and language of the post-independence ideological discourse. The final section of "The Idea of National Independence" outlines how the new ideology is to be disseminated throughout society. It contains subheadings on "Upbringing and Education", "Art and Literature", "Physical Culture and Sport", "Work Collectives", and "The Media", which would not have been out of place in a similar Soviet document. The section on sport, for example, talks about physical culture as an important element in moral and spiritual perfection. The document contains a section entitled "The Perfect Person" (komil inson) that begins with the statement, "The complete person is one who strives continually to embody, in both national and universal human terms, a moral and physical perfection" (MIG: 56), which clearly echoes the harmonious and complete person of Soviet discourse.

Other subheadings in the final section of this document, "Religion" and "The Mahalla", indicate how the post-independence ideology is also an essential departure from the Soviet project, and the difference turns on its vision of culture. Laura Adams has produced a convincing and thorough analysis of the post-independence Uzbekistan as an elite project of nation building through culture, and how this project both drew upon Soviet concepts of culture and nationality, while also developing along its own distinctive path (Adams 2010). At the heart of the new ideology is the idea of an Uzbek authenticity. This is rooted in the oltin meros (Golden Heritage), the historically developed complex of distinctly Uzbek spiritual values and national personality traits, embodied in the great philosophers, scientists, writers and Islamic thinkers who lived in the territory of present day Uzbekistan. It finds expression in the notion of ma'naviyat, which might be translated as spirituality or morality. As developed in state ideological production this is the embodiment in the individual of the authentic cultural and spiritual heritage (Kendzior 2014). A nationwide network of centres for "Spirituality and Enlightenment" (ma'naviyat va ma'rifat), have been established to promote the 
government's ideas about national spiritual development, and the prolific ideological writings authored by the president are required reading in schools and universities.

Post-independence ideology is founded on an essentialist conception of culture, as a "spirit of a people" that shapes their values and mentalities (MIG 9-21). It inherits this concept from the Soviet understanding of ethnonational development, but where the Soviet project sought to reduce national culture to a folkloric form, and to fill this form with a socialist consciousness, post-independence ideology is founded on the idea of an Uzbek cultural and spiritual authenticity. The new national vision looks forward to economic and scientific development, but Uzbekistan needs to take its own, culturally and spiritually authentic path and have its own system of government. This might of course be seen as window dressing for authoritarian rule, central control of the economy, and an excuse for the lack of any real popular representative democracy and personal freedoms. But the essentialist notion of culture as Uzbek authenticity nevertheless shapes the nature of the political in distinctive ways.

The Soviet ideological project viewed the human subject as pliable material that could be transformed through the shaping of consciousness. This consciousness both reflected, and also produced, a socialist ordering of society. Cultural survivals were placed in opposition to a socialist kul'turnost'. This opposition within the Soviet political imaginary, that also produced categories of class enemies and allies, provided the logic through which state organs and personnel could intervene in society. This logic shaped the terms in which Soviet citizens needed to reproduce themselves, in public space, as "correct" Soviet persons. In post-Soviet Uzbekistan the opposition is between an authentic "Uzbekness" and foreign, dangerous ideas that are alien to the essential cultural and spiritual being of Uzbek society. Legitimate membership of society is framed in terms of an authentic, embodied culture, as a natural and essential quality of the person (Kendzior 2014). Ideology, here, is intended to develop and reinforce a morality that is viewed as natural to the Uzbek person. Those who in some way are seen as inauthentic, are placed outside the body politic as unnatural, perverse or misguided, hence the need for ideological "immunisation". ${ }^{8}$ While in neighbouring Kyrgyzstan converting to Christianity might be seen as a cultural or ethnic transgression with social consequences in a local community, in the political imaginary of independent Uzbekistan, cultural inauthenticity is a national betrayal, a public affair of state, and national security is embodied in the Uzbek person. Islamic practice is 
acceptable if it is perceived to be rooted in Central Asian traditional practice, but anything which can be characterised as odd, unusual or foreign is vulnerable to being characterised as dangerous extremism and "Wahhabism".

\section{The space for Islam}

Since independence, the space for Islam has been vastly expanded, in the sense that the post-independence government has allowed Islam a much larger public presence. Thousands of mosques have been built, the tombs of Central Asians prominent in Islamic history, such as Imom al-Bukhoriy and Bahouddin Naqshband, have been lavishly renovated as national monuments at state expense, and madrasas have been established throughout the country to provide Islamic education. But the government continues to regulate religious expression closely, and represses interpretations of Islam that stand outside its discursive construction of cultural authenticity. In comparison to most Muslim societies, including neighbouring countries like Kyrgyzstan and Kazakhstan, open debate over what constitutes correct Islam and what it means to be Muslim are severely muted. The government regulates Islamic practice and orthodoxy through the Muslim Board of Uzbekistan, which manages the madrasas and mosques, appoints the imams to registered mosques (the only ones in which the main Friday prayers and sermon can be held), and drafts the themes for the Friday sermon.

Official imams are expected to promote officially sanctioned expressions of Islam and to monitor the population for signs of "extremism". However, the construction of Islam within state discourse, as subordinated within a locally authentic cultural and spiritual heritage, contradicts their own understandings in fundamental ways. Imams are not simply government functionaries. All those I encountered during my field research were engaged in a sincere study of the Islamic textual tradition, and committed to transmitting correct knowledge of Islam and what it means to be a Muslim, as they understood this to be. Much of what state discourse extols as an authentic Central Asian spiritual heritage is considered by madrasa trained imams as the product of fallible human tradition (urf-odat), survivals of pre-Islamic ritual. Practices they criticise, in addition to the extended feasting associated with life cycle rituals already referred to, include visiting the tombs of avliyo, or "saints", or seeking the services of practitioners who heal or prophesy with the help of spirits (Rasanayagam 2011: 138-143; Kehl-Bodrogi 2006). At the same time, however, the Muslim Board and 
its imams are required actively to support and enforce government policy. Imams are forced to be circumspect, and their freedom to condemn what they consider to be unIslamic innovation is constrained.

The way that the quasi-state Islamic religious establishment negotiates this tension is evident in its criticism of excessive expenditure at ritual events, such as weddings and funerals, which were alluded to in the previous section. Guidance on the conduct of household ritual events is included in a manual produced for the leaders of mahalla committees by the National Mahalla Foundation and the Ministry of Justice. ${ }^{9}$ The manual consists of a collection of laws, articles of the constitution, presidential speeches and decrees, and decisions of the Cabinet of Ministers, which relate to the activities of the mahalla. ${ }^{10}$ Two sections deal specifically with the conduct of ritual events, both of which are framed in terms of reducing overly extravagant display and expense. The first of these is a document produced by the National Mahalla Foundation and the National Women's and Girls' Commission entitled "Advice on the conduct of national traditional customs, feasts, funeral rites and other national ceremonies in light of the present need for streamlining and economising". ${ }^{11}$ It is presented in tabular form, providing a list of ritual events, advice on how to conduct them in terms of how many and which categories of people to invite, the significance and meaning of each occasion, and advice on how to reduce expenditure.

In the section on weddings thirteen separate events are listed, beginning with the fotiha yuborish at which the fotiha, the first sura of the Qur' an, is recited by senior family members and the date of the wedding set, proceeding through the civil registration and the main wedding feasts (at which 400-600 guests are stipulated), and ending with the kelin ko'rish after the bride has settled into her new household (usually the husband's family's), at which the bride's natal family present gifts to the couple and to the groom's family. Other rituals covered include those concerning birth and circumcision, and the section on death lists ten rituals. These include the three day mourning period, gatherings three or seven days after the funeral for close relatives, a twentieth day commemoration feast (at which 300-400 participants are suggested), a fortieth day commemoration and an event to mark the first falling of snow after the death. In describing the significance of ritual events Islamic norms are sometimes referred to. For example, when describing the aqiqa ceremony for the birth of a child the document states that within Islam one third of the sheep sacrificed for the occasion 
is kept and two thirds have to be distributed as ehson, charitable giving. Other events, such as all the death commemorations except the initial three days of mourning, are described as ceremonies not stipulated within the $\operatorname{sharī'}^{\prime} a$.

In fact, this list does not cover all the ritual events that households host. For example, it does not mention the mavlud, commemoration of the birth of the Prophet, which has become popular in recent years. Moreover, most households would not hold the full series of rituals concerning marriage and death, and in my own field research sites aqiqa ceremonies were relatively rare. The document is intended as advice for mahalla leaderships with the aim of reducing what the government considers to be wasteful and extravagant expenditure on ritual occasions. At the same time, the effect of the document is to reify and authorise the idea of a body of traditional ritual, some of which may have some reference to Islam but which is primarily national in essence, part of the government's discursive construction of "Uzbekness".

The second document concerning the conduct of rituals in the manual is a fatwa issued by the Mufti, the head of the Muslim Board. It instructs the imams of registered mosques to warn their congregations through their Friday sermons of the evils of extravagance and vanity in the conduct of ritual feasts and funeral commemorations. The fatwa is clearly intended as a support for the government's policy and makes an effort to fit in with state discourses. It declares that rituals should be conducted in accordance with both religious (diniy) and national (milliy) norms, and that extravagant spending at weddings is contrary to "our eastern civilisation", echoing the government's discourse on the unique Central Asian cultural and spiritual heritage. At the same time, it singles out the series of commemorative rituals surrounding death for special mention, held on the seventh, twentieth and fortieth day, and one year after the funeral, which it describes as connected with "custom" (odat). It goes further than the previously mentioned document in that it instructs imams to point out that these not only are not stipulated in the $\operatorname{sharī'}^{\prime} a$, but might actually be bid'at, illegitimate innovation that is unacceptable for Muslims. ${ }^{12}$ Although the wording seems chosen so as to avoid contradicting government discourse too directly, it cannot avoid suggesting an alternative frame for understanding custom and tradition, not as a celebrated foundation for an authentic Uzbek model of progress and development but as a contingent human artefact in opposition to the divine Truth of the $\operatorname{sharī}^{\prime} a$. 
The state established ulama of the Soviet era Muslim Spiritual Directorate for Central Asia and Kazakhstan (SADUM) occupied a similarly ambiguous position. In his comprehensive history of Islam in the Soviet Union, Yaacov Ro'i documents how the Spiritual Directorates (there were four, each administrating a separate region of the USSR) issued fatwas in support of Soviet state objectives. These included fatwas on the conduct and observance of Islamic festivals in order to avoid absenteeism and damage to the economy. Other fatwas sought to limit the expenses on the iftor feasts breaking the fast during Ramadan. Many were in support of Soviet policy towards women, proclaiming their right to education or stressing that veiling was not obligatory, and some, in common with the post-independence fatwa referred to here, criticised wasteful spending on weddings and circumcisions as sinful (Ro'i 2000: 140-155). The Soviet-era ulama had to accommodate themselves to the imaginary of the Soviet project.

The state established ulama of the Soviet era Spiritual Directorates and the postindependence Muslim Board operate within the logic of the political imaginaries of those respective state regimes, but they are not mere mouthpieces for central government. Mark Saroyan has described the Soviet ulama as both fundamentalist and accommodationalist; fundamentalist because of their dedication to promoting a scripturally founded interpretation of Islam, purifying local practice from unscriptural innovation. He argues that they also sought to rework the Soviet discourse of the New Soviet Person, to show that Muslims could be active participants in Soviet society (Saroyan 1997). While establishment ulama, both Soviet and post-Soviet, support state policies, they also inhabit their own, Islamic conception of truth and authenticity, as the fatwa reproduced in the manual for mahalla leaderships shows. Their relation to the hegemony of state ideology cannot be captured in straightforward terms of domination and resistance.

The imams in charge of mosques registered with the Muslim Board whom I encountered did not express any opposition to state ideology, and supported government policies and pronouncements in their sermons, for example condemning religious extremism and groups such as Hizb ut-Tahrir. But they also preached what they understood as correct Islamic practice (Rasanayagam 2011: 138-43). Many of the imams I encountered in Samarkand were from families who had been imams or Islamic scholars in the pre-Soviet era, and had maintained a level of Islamic learning through the Soviet period. Before graduating from the state controlled madrasas in independent 
Uzbekistan, they had received Islamic education from their fathers or grandfathers. The father of one had been an official imam of one of the few Soviet era mosques allowed to operate in the city, and another claimed descent from the 15th century Naqshbandi scholar Sayyid Ahmad Kosoniy, known as Makhdum-i A’zam. They occupied a Muslim imaginary which is starkly in opposition to that of Uzbekistan's Ideology of National Independence, an opposition which is brought into sharp focus in the attitude to national culture, but they did not actively resist it.

The Soviet space for Islam was one which excluded the public performance of Islamic ritual. It was one of discrete shrine visitation, or rituals invoking spiritual intercession such as the bibiseshanba. For some, it was the private performance of prayer in the home, or visiting mosques by older generations. It was the space of lifecycle rituals which invoked a Muslim frame, such as circumcisions, weddings, and funerals, which located and reproduced a person within a moral community. This is what Maria Louw has called "everyday Islam", and in large part what Central Asian Muslims encompass with the term musulmonchilik, or Muslimness (Louw 2007; Privratsky 2001). This is not to say that such practice was merely cultural, if by the term culture we mean to draw a distinction between being Muslim as an ethnonational marker of identity, as opposed to Islam as stance of belief, devotion and piety, founded on a relation to the core sacred texts of Islam; secular culture as opposed to spiritual belief. This opposition occludes the possibility that much of what might be perceived as "traditional", non-scripturally founded practice of Muslims, is in fact a moral engagement with the transcendent, and contributes to the development of moral and Muslim selves. Maria Louw has described the "ironic" stance of residents of Biskhek in Kyrgyzstan who with some embarrassment, recount visits to clairvoyants and healers. On one level, they view this as pre-modern, superstitious, and un-Islamic practice. At the same time, these visits, and their encounters with signs of God in dreams, and when performing prayers, are transcendent sites for the contemplation of moral self and society (Louw 2012). Refracted through the Soviet imaginary, all this was understood as either pre-modern "survivals" or expressions of a folkloric "national culture".

In the imaginary of the post-independence state, the space for Islam has shifted. Cultural authenticity is the criterion through which the government intervenes in society to distinguish between those who belong and dangerous, foreign elements, whom the cry of "Wahhabi" has come to represent. These are the terms in which a person needs to 
reproduce him or herself as a proper citizen. This makes sense of why the particular charge of Wahhabism was levelled at Ahmadjon and others in Arabkhona Mahalla who had converted to Christianity by their neighbours. With this charge, the affair is placed in the public sphere and the state security services come to be employed within neighbourhood disputes. What these individuals are really speaking to is the inauthenticity of a Christian Central Asian, within the terms of the new state imaginary. They know that Wahhabism is a specifically Islamic tendency, and that a Christian cannot be a Wahhabi, but they also know that being "inauthentic" can make a person vulnerable, a public threat to national security.

\section{Word count: 7420 excluding notes and references.}

\section{Notes}

${ }^{1}$ For ethnographically grounded accounts of how politics, including ideology, is performed in Central Asia see (Reeves, Rasanayagam, and Beyer 2014).

2 The ethnographic research on which this article is based was carried out between July 2003 and August 2004 in the city of Samarkand and in a village near the city of Andijan.

${ }^{3}$ Uzbekistan retains the Soviet administrative practice of registering citizens both in terms of ethnonational belonging (natsional'nost' in Russian, millat in Uzbek), and state citizenship (grazhdanstvo or fuqarolik).

${ }^{4}$ Shirin Akiner also argues that Islam was reduced to what she calls an 'ethnocultural' rather than a religious allegiance (Akiner 1996), and Yaacov Ro'i writes about the 'secularisation' of Islam in the USSR (Ro’i 1995).

${ }^{5}$ Mathijs Pelkmans has described how this dynamic works out in missionary activity in neighbouring Kyrgyzstan (Pelkmans 2007).

${ }^{6}$ See for example Poliakov (1992). Deniz Kandiyoti and Nadira Azimova have critiqued the use of the frame of tradition and modernity in Soviet ethnographic accounts of Islam in Central Asia (Kandiyoti and Azimova 2004).

${ }^{7}$ See March (2003) for an analysis the discourse of the 'spiritual vacuum' in Uzbekistan's postindependence ideology. 
${ }^{8}$ Nick Megoran has written about President Karimov's use of the trope of an authentic Uzbekness in his response to the events in Andijan in May 2005, when hundreds of protests were gunned down by the security forces (Megoran 2008).

${ }^{9}$ The mahalla is a residential subdistrict which also acts as a social institution. While in the pre-Soviet and Soviet eras various forms of community institutions existed in rural settlements and in the old quarters of cities, the post-independence government has formalised these as mahalla with a locally elected leadership committee. It has extended the network of mahalla to cover all residential districts, even those made up of highrise apartments, although in areas in which it has been relatively recently imposed the mahalla has little social relevance (Rasanayagam 2011: 49-58).

${ }^{10}$ Mahalla: fuqarolar o'zini 'yzi bosqarishining huquqiy asoslari. 2003. Tashkent: O'zbekiston 'Mahalla' khayriya jamg'armasi.

${ }^{11}$ Respublicada mavjud an 'anaviy udumlar, to'ylar, dafn ma 'rakalari va boshka milliy marosimlar va ularni zamon talablariga javob beradigan tarzda, ihcham hamda tejamkorlik bilan u'tkazishga qaratilgan tavsiyalar

${ }^{12}$ Marhumlar dafnidan keyin odat tucsiga aylangan 7, 20, 40, yil, hayit kunlaridagi fotihaxonlik kabi marosimlarning shar'iy emasligi, balki bid'at ishlardan ekanligi tushuntirib borilsin.

\section{Acknowledgements}

Versions of this article have been presented at Humboldt University and the University of Exeter, and benefited greatly from feedback received on those occasions. I would particularly like to thank Maria Louw and Alex King for their comments on earlier drafts, and also the very useful suggestions of the editor and anonymous reviewers of Central Asian Survey.,

\section{References:}

Abashin, Sergei. 1999. "Vopreki 'zdravomu smyslu'? (K voprosu o 'ratsional'nosti/irratsional'nosti ritual'nykh raskhodov v Srednei Azii)." Vestnik Evrazii 1-2 (6-7): 92-112. 
Adams, Laura L. 2010. The Spectacular State: Culture and National Identity in Uzbekistan. Durham: Duke University Press.

Akiner, Shirin. 1996. "Islam, the State and Ethnicity in Central Asia in Historical Perspective." Religion, State and Society 24 (2/3): 91-132.

— 1997. "Melting Pot, Salad Bowl - Cauldron? Manipulation and Mobilization of Ethnic and Religious Identities in Central Asia." Ethnic and Racial Studies 20 (2): 362-398.

Hirsch, Francine. 2005. Empire of Nations: Ethnographic Knowledge and the Making of the Soviet Union Ithaca: Cornell University Press.

Hoffmann, David L. 2003. Stalinist Values: The Cultural Norms of Soviet Modernity, 1917-1941. Ithaca: Cornell University Press.

Kandiyoti, Deniz, and Nadira Azimova. 2004. "The Communal and the Sacred: Women's Worlds of Ritual in Uzbekistan." Journal of the Royal Anthropological Institute (N.S.) 10 (2): 327-349.

Kapferer, Bruce. 1988. Legends of People, Myths of State: Violence, Intolerance, and Political Culture in Sri Lanka and Australia. Washington: Smithsonian Institution Press.

Karimov, Islam. 1997. Uzbekistan on the Threshold of the Twenty-First Century: Threats to Security, Conditions of Stability and Guarantees for Progress. Tashkent: Uzbekiston.

Kehl-Bodrogi, Krisztina. 2006. "Who Owns the Shrine? Competing Meanings and Authorities at a Pilgrimage Site in Khorezm " Central Asian Survey 25 (3): 235250. 
Kendzior, Sarah. 2014. "Reclaiming Ma'naviyat: Morality, Criminality and Dissent Politics in Uzbekistan". In Ethnographies of the State in Central Asia: Performing Politics, edited by Madeleine Reeves, Johan Rasanayagam and Judith Beyer. Bloomington: Indiana University Press.

Khalid, Adeeb. 2003. "A Secular Islam: Nation, State, and Religion in Uzbekistan." International Journal of Middle East Studies 35 (4): 573-598.

Khalid, Adeeb 2007. Islam after Communism: Religion and Politics in Central Asia. Berkeley: University of California Press.

Kharkhordin, Oleg. 1999. The Collective and the Individual in Russia: A Study of Practices. Berkeley: University of California Press.

Kotkin, Stephen. 1995. Magnetic Mountain: Stalinism as a Civilization. Berkeley: University of California Press.

Liu, Morgan Y. 2012. Under Solomon's Throne: Uzbek Visions of Renewal in Osh. Pittsburg: University of Pittsburg Press.

Louw, Maria Elizabeth. 2007. Everyday Islam in Post-Soviet Central Asia. London: Routledge.

. 2012. "Being Muslim the Ironic Way: Secularism, Religion and Irony in PostSoviet Kyrgyzstan". In Varieties of Secularism in Asia: Anthropological Explorations of Religion, Politics and the Spiritual, edited by Nils Bubandt and Martijn van Beek. London and New York: Routledge.

March, Andrew. 2003. "State Ideology and the Legitimation of Authoritarianism: The Case of Post-Soviet Uzbekistan." Journal of Political Ideologies 8 (2): 209-232. 
Medlin, William K, William M Cave, and Finley Carpenter. 1971. Education and Development in Central Asia: A Case Study on Social Change in Uzbekistan. Leiden: E.J. Brill.

Megoran, Nick. 2008. "Framing Andijon, Narrating the Nation: Islam Karimov's Account of the Events of 13 May 2005." Central Asian Survey 27 (1): 15-31.

Omelicheva, Mariya Y. 2011. "Islam in Kazakhstan: A Survey of Contemporary Trends and Sources of Securitization." Central Asian Survey 30 (2): 243-256.

Pelkmans, Mathijs 2007. "'Culture' as a Tool and an Obstacle: Missionary Encounters in Post-Soviet Kyrgyzstan." Journal of the Royal Anthropological Institute (N.S.) 13 (4): 881-899.

Poliakov, Sergei P. 1992. Everyday Islam: Religion and Tradition in Rural Central Asia. London: M. E. Sharpe.

Privratsky, Bruce. 2001. Muslim Turkistan: Kazak Religion and Collective Memory. Richmond: Curzon.

Rasanayagam, Johan. 2006. "I'm not a Wahhabi: State Power and Muslim Orthodoxy in Uzbekistan". In The Postsocialist Religious Question: Faith and Power in Central Asia and East-Central Europe, edited by Chris Hann and the 'Civil Religion' Group. Berlin: Lit Verlag.

- 2011. Islam in Post-Soviet Uzbekistan: The Morality of Experience. Cambridge: Cambridge University Press.

Reeves, Madeleine, Johan Rasanayagam, and Judith Beyer, eds. 2014. Ethnographies of the State in Central Asia: Performing Politics. Bloomington: Indiana University Press. 
Ro'i, Yaacov. 1995. "The Secularisation of Islam and the USSR's Muslim Areas". In Muslim Eurasia: Conflicting Legacies edited by Yaacov Ro'i. London: Frank Cass

-2000. Islam in the Soviet Union: From the Second World War to Gorbachev. London: Hurst and Company.

Saroyan, Mark. 1997. "Islamic Clergy and Community in the Soviet Union". In Minorities, Mullahs and Modernity: Reshaping Community in the Former Soviet Union, edited by Edward W Walker: University of California Press/University of California International and Area Studies Digital Collection.

Scott, James. 1985. Weapons of the Weak: Everyday Forms of Peasant Resistance. New Haven: Yale University Press.

Shahrani, Nazif. 1995. "Islam and the Political Culture of "Scientific Atheism" in PostSoviet Central Asia: Future Predicaments". In The Politics of Religion in Russia and the New States of Eurasia, edited by Michael Bourdeaux. New York: M.E. Sharp.

Slezkine, Yuri. 2000. "The USSR as a Communal Apartment, or How a Socialist State Promoted Ethnic Particularism". In Stalinism: New Directions, edited by Sheila Fitzpatrick. London: Routledge.

Taylor, Charles. 2004. Modern Social Imaginaries. Durham: Duke University Press. 2007. "What is Secularity". In Transcending Boundaries in Philosophy and Theology: Reason, Meaning and Experience, edited by Kevin Vanhoozer and Martin Warner. Aldershot: Ashgate. 
Trisko, Jessica N. 2005. "Coping with the Islamist Threat: Analysing Repression in Kazakhstan, Kyrgyzstan and Uzbekistan." Central Asian Survey 24 (4): 373389.

Yurchak, Alexei. 2006. Everything was Forever, until it was No More: The Last Soviet Generation. Princeton: Princeton University Press.

Zanca, Russell. 2005. "Believing in God at Your Own Risk: Religion and Terrorisms in Uzbekistan." Religion, State and Society 33 (1): 71-82.

\section{Government documents:}

Mahalla: fuqarolar o’zini ‘yzi bosqarishining huquqiy asoslari. 2003. Tashkent: O’zbekiston 'Mahalla' khayriya jamg'armasi.

Milliy istiqlol g’oyasi: asosiy tushuncha va tamoyillar. 2001. Tashkent: : O’zbekiston. 